\title{
UDC 378.147:378.011.3-051]:378.046-021.68:[17.022.1:378.4]
}

\section{Mykola Lokhonya \\ Sumy State Pedagogical University named after A.S. M akarenko ORCID ID 0000-0003-0778-252X \\ DOI 10.24139/2312-5993/2020.10/157-166}

\section{THEORETICAL BASIS OF FORM ATION OF FUTURE TEACHERS' READINESS TO CREATE THE HIGHER EDUCATION INSTITUTION IMAGE}

Education is an integral part of the life of society, on the development of which the intellectual and spiritual potential of the country depends. With penetration of market relations into the educational sphere, globalization of educational services, on the one hand, and the peculiarities of the demographic situation in our country, on the other, the role of marketing and PR technologies in shaping the image of higher education institutions is difficult to overestimate. Thus, the theoretical foundations of formation of the readiness of future teachers for creating the image of the education institution not only enhances the importance of an individual university, but also influences formation of the image of education as a whole.

Key words theoretical basis, formation, future teachers' readiness, higher education institution, image.

Introduction. Within the framework of globalization, the role of universities in society is changing, which are considered as centers of not only educational and scientific, but also innovative, economic and cultural activity. Their main task is to provide a contribution to the socio-economic development of the "knowledge society". The reduction in state funding contributed to the commercialization of the work of universities, which resulted in an increase in the number of students, especially foreign ones, in the desire to earn additional funds through grants, additional paid educational services, etc.

Globalization orients higher education towards implementation of the market activities and makes changes in the research focus of the formation of future teachers' readiness to create the higher education institution image.

Considering the image issue, one should not miss such a characteristic of the image as efficiency: the university goal, like any organization, is to form an effective, favorable image that forms harmonious relations with the public. An effective image increases competitiveness in the educational market. It attracts applicants and the teaching staff, the teaching level rises and, accordingly, the graduates' level rises. This makes it easier for the organization to access various resources: financial, informational, human, material. The image should be targeted and consistent with the expectations of consumers of educational services. For well-known universities, the task of building an effective image may seem easy, since the previously acquired image helps to withstand the competition. However, changes in the external environment can dramatically 
change the balance of power and affect the university image. To form a positive and effective university image, which serves as one of the competitiveness components in the educational services market, a system of events is needed: marketing, PR, advertising, etc.

Consequently, there is a need for a comprehensive research analysis of the theoretical bases of formation of future teachers' readiness to creation of the higher education institution image.

Analysis of relevant research. The subjects of the higher education institution image formation are the institution itself and the image "creators", usually represented by the interest groups. Image is usually created as a result of the interplay between two elements, as an integration of the information presented by the organization and the selected communication instruments (K. Boulding, J. E. Dutton, G. R. Dowling, P. M artineau). The important moment in this case is that a particular education institution is an integrated part of the higher education system, and its image is not absolute but related to the images of other higher education institutions (Druteikiene et al., 2007). Therefore, the entire higher education system could be considered as the image subject of a higher education institution.

Special literature on imageology, marketing, public relations and advertising shows that the "image" concept is often mixed with other, semantically close, but not identical concepts of reputation, stereotype, appearance, brand, image, media image (P. Kotler, M. Bergami).

Thus, the issues of the theoretical bases of formation of future teachers' readiness to creation of the higher education institution image are becoming relevant nowadays.

The aim of the article. To characterize the theoretical bases of formation of future teachers' readiness to creation of the higher education institution image.

Research methods: Solving the highlighted tasks, a set of methods of scientific research adequate to them were used, theoretical: a comparative analysis of the scientific definitions of the theoretical bases of formation of future teachers' readiness to creation of the higher education institution image, a systematic analysis of traditional and innovative formation components of future teachers' readiness to creation of the higher education institution image.

Results. Image is a term that causes great debate among scientists all over the world. Each author using this term gives it his own meaning. In the United States of America, it was used various times as a synonym for the concepts of reputation, brand, corporate identity, perception, attitude, communication. J. Ballmer (Balmer, 1999) noted that the image has more in common with illusions 
and half-tones than with reality. This outdated approach assumed that companies could create their image out of nothing and that their behavior and relationships with customers mattered little. Outside the USA, the attitude towards the image was somewhat different, more positive. In the writings of scientists from Greece (Helms, 1994) and India (Parameswaran, 1995) image was studied as an integral part of all relationships of the company with its target audiences. Also, the image appeared in publications on international relations in the aspect of the countries and regions image (Nagashima, 1970; Nagashima, 1977). The etymology of the term "image" is associated with the Latin word "imago", it is a tracing paper from the English word "image", which is translated as a look, an image. The term was introduced into scientific circulation in 1955 by the American E. Bernays in the book "Engineering of Consent" (Бернейс, 2013).

In 1978, P. Browne (Browne, 1974) suggested that the first meaning of the term image was "copy, replica". He also cited a historical background that had already appeared in the works of Aristotle, John Locke, David Hume and John Stuart Mill, the image stood out as the main thinking element. In 1995, F. Kotler and $K$. Fox defined the image as a set of ideas, beliefs and impressions that $a$ person has about an object (Kotler, 1995). F. Kotler and K. L. Keller attributed the image to the subject of marketing, justifying this by the fact that companies are actively working to create a strong and favorable image in the minds of their potential customers. "Universities, museums, concert halls, non-profit organizations use marketing to create a positive image for themselves, as it is one of the main success components in the struggle for funds and audience". (Csaszar, 2015). 20th century public relations and marketers used the image concept as a complex concept of attitude, cognition, perception and belief (Belanger, 2014).

Commonly, image is described as an attitude regarding a specific object created in the mind of an individual or a group, based on all visually and verbally received information (Baker, 2001). A broader explanation of image describes it as a "summation of ideas, feelings, comprehension and imagination of an organization from the perspective of an individual or a group, which is influenced by material and immaterial organizational elements, communication, personal and social values" (Druteikiene, 2007).

Studying the differences between image and corporate identity, they came to the conclusion that image is how consumers perceive the organization, corporate identity is what means the organization uses to form a certain perception. It was widely believed that emergence of the concepts of corporate identity, image and reputation was a reaction to an increase in the general level of competition in the world and increased pressure on business. The 
pressures were the acceleration of the product life cycle; weakening of government control and regulation; globalization; shortage of highly qualified staff; overestimated public expectations regarding corporate responsibility. Some authors have put forward the idea that the organization image is a shortterm phenomenon and refers to the specific organization perception at a given point in time (Bergami, 2000; Dutton, 1991). At the same time, many of them had not seen the difference between the image concept in the meaning of the message purposefully created by the company for its consumers, and the artistic and psychological concept (Kotler, 1995).

From the point of social sciences view, one of the most developed theoretical approaches to formation of future teachers' readiness to create the higher education institution image is impression management - the image is considered as the impression that an individual or organization makes on others. Many researchers define image as synonymous with reputation (Dowling, 1993), but within this study framework, the image will be considered as an independent concept (Dutton, 1994; Elsbach, 2003).

It should be noted that the process of the formation of future teachers' readiness to create the higher education institution image does not go beyond advertising and public relations, although this concept itself is much broader. $M$ any factors in the image formation are not completely clear, others should be revised in the light of modern knowledge and experience.

In the twentieth century, in the scientific research course in the field of business, the concept of corporate image was formulated. P. Martineau (M artineau, 2003) and K. Boulding (Boulding, 1956) had a significant impact on the growth of interest in the concept of image in a business context. K. Boulding suggested the existence of a connection between the organization image and the people's attitude towards it. P. Martineau proved that a favorable image gave stores a competitive edge. His research showed that shoppers tended to associate themselves with certain stores. They felt more comfortable in those who coincided with their idea of their own social position. According to P. Martineau, non-price factors became the hallmarks of retail stores.

The formation and management complexity of the corporate image P. Martineau associated with the need to interact with different target audiences, each form has own idea of the company. In this regard, he put forward the concept of a stereotypical image, the essence is that perception of a company may differ among individuals and groups, while the stereotype should be the same for all stakeholders. 
It should be noted that formation of future teachers' readiness to create the higher education institution image, is one of the PR activities tasks, therefore the main tools used to build an image or correct it are tools of public relations. To develop an effective program for optimizing the university image, it is necessary to clearly understand the target groups that will get key messages and views, opinions and assessments of which are important for the formation of future teachers' readiness to create the higher education institution image. The public relations specialists of the university should build interaction with these groups.

Thus, formation of future teachers' readiness to create the higher education institution image is a process that develops under the influence of a number of factors and interdependent actions, the result of perception by various public groups of this organization. The image is interconnected with such social categories as a person, a group of people, organizations and results of their activities. In the public minds, the image idea as a value that influences the success of any activity is becoming stronger. To determine the process role of the formation of future teachers' readiness to create the higher education institution image, a complex scheme was drawn up in the form of Figure 1, which shows how the five categories affect all stages of the described process.

As can be seen from the presented figure, the primary political task is the formation of corporate identity (values and goals, corporate strategy, organizational culture and structure), on the basis of which primary and secondary communication related to the economic category is built.

Through the ethical category of stakeholders, the corporate image formation and reputation takes place, which, under the influence of external factors, stimulate tertiary communication, allow, with the feedback help, to correct corporate identity and gain competitive advantages. A review of numerous works by scientists and practitioners exploring various aspects of image formation has shown that image is a multi-faceted category. This makes it possible to substantiate the possibility of considering the term "image" in relation to a higher education institution acting as a subject of the services market. Today the concept of "corporate image" is becoming more and more applicable to the educational environment and its subjects. The image of a higher education institution is an image specially designed for potential consumers of educational services and other groups of stakeholders', which must meet their expectations and needs. 


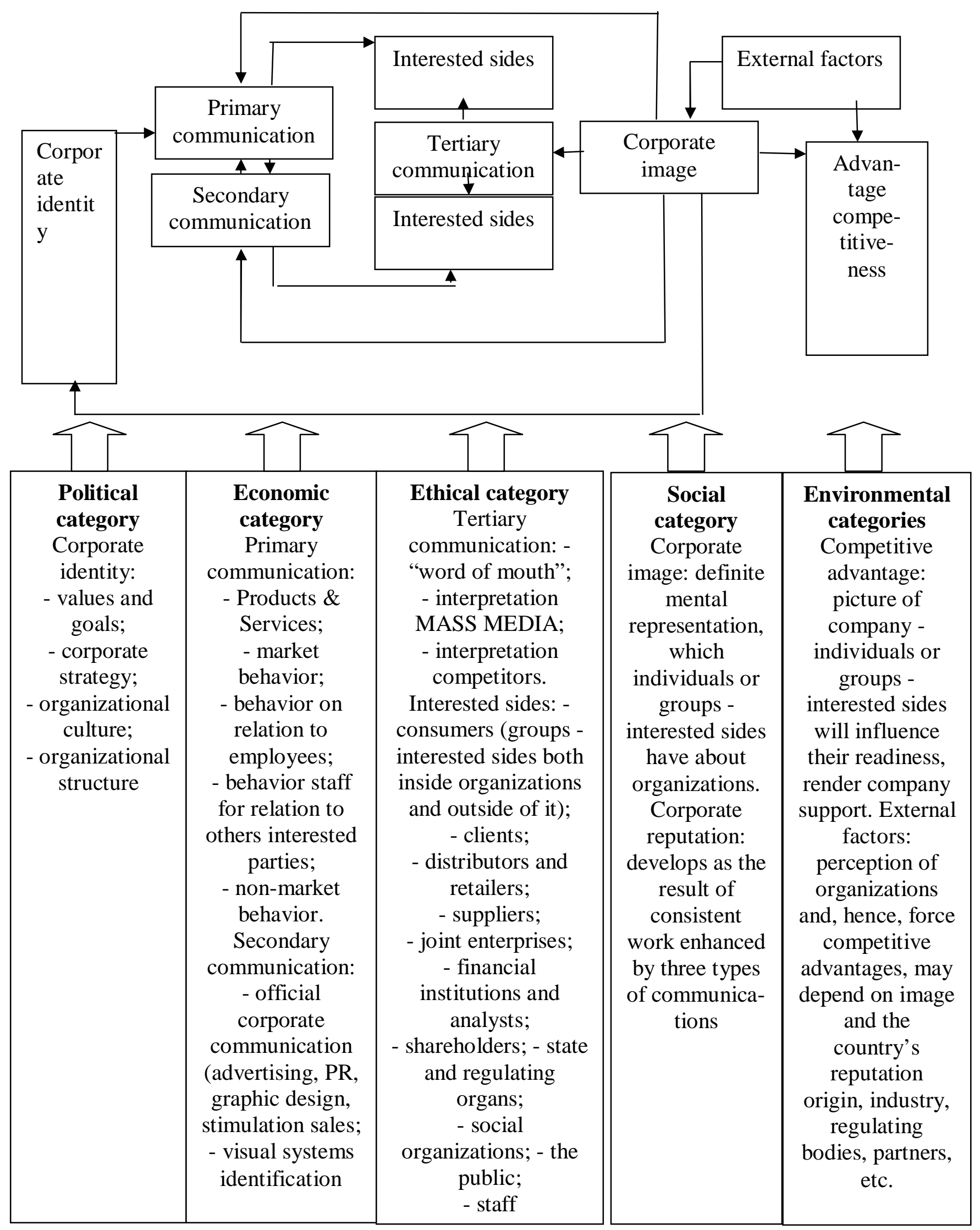

Figure 1. The role of image in the formation of the higher education institution competitiveness 
The main target groups, interaction with which are necessary to the formation of future teachers' readiness to create the higher education institution image, include applicants and their parents, university graduates, partners, government bodies, the media, faculty and support staff, as well as students of the university. It should be noted that formation of future teachers' readiness to create the higher education institution image, which forms the symbolic and public capital of an organization or person (PR-subject), is one of the tasks of PR activities, therefore, the main tools used to build an image or correct it are technologies and tools of public relations. Public relations specialists use a variety of technologies: media relations, event-marketing, sponsorship and charity, investor relations, intracorporate communications, network and electronic PR, as well as tools and techniques that facilitate their implementation.

It should be noted that formation of future teachers' readiness to creation of the higher education institution image, forming the symbolic capital of an organization or person, is one of the tasks of PR activities, therefore, the main tools for the formation of an image or its correction are public relations. Developing an effective optimization program for the university, it is necessary to clearly understand the target groups that will be addressed, key messages and views, opinions and assessments of which are important for the formation of future teachers' readiness to creation of the higher education institution image. With these groups, the interaction of the university's public relations specialists should be developed. They include:

1. Applicants and their parents as one of the priority target groups in implementation of the university image strategy. The value of this group is due to the challenge facing universities to expand the market for educational services, increasing its volume by attracting the largest number of motivated talented applicants. In accordance with the preferences of applicants, they emphasize the high status of the university, the specialty prestige, the education quality, employment opportunities, students' social security.

2. University graduates are the target group, as they form the external university image among employers and themselves will become parents of potential applicants in the future.

3. It is important for the university to interact with a partners group employers, business representatives. The purpose of working with this audience is media sphere and media education: achieving loyalty to the university, to convince partners of the education quality. It is important to give rational arguments in favor of this university graduates, under point out the usefulness and education quality. 
4. Government, government bodies are needed to lobbying the interests of higher education and the university itself, influencing efforts to resolve issues of financing and other related university activities.

5 . When building relationships with authorities, it is necessary to show how the university understands the importance of social responsibility of the organization, society, city, country: participation of teachers, students and tellers in public life, charity events, etc.

6 . The media is a target group that influences formation of future teachers' readiness to creation of the higher education institution image through coverage of its activities and performance university evaluation.

7. The faculty and support staff are target internal audiences that play an important role in the organization of the educational process and represents the university to external audiences. The faculty and other staff jould take part in the formation of the university mission and values and in managing it.

8. Students and listeners - the target audience, the behavior and opinion of which influences the public perception of the university. In the case of an effective communication of the teaching staff with students they become devoted and grateful during the studying years. Thus, formation of future teachers' readiness to creation of the higher education institution image is created by formation of external (image of educational services, consumers educational services, leader, teachers, students and listeners, visual, social and business image) and internal images. They are based on the unique characteristics of the university, lifestyle and social status of all students' parents, status of students, applicants, graduates and partners, on the nature of the relationship between teachers, students, university leadership and government bodies, starters, employers. In today's market, everyone needs an image and there is a need for the development and application of PRtechnologies for the formation of future teachers' readiness to creation of the higher education- institution image and effective management of it.

Conclusions. The relative novelty of image research, unclear concepts and sometimes different approach to it in scientific literature complicate the perception of a higher education institution's image. M ost publications see this category as a multilevel process with the versatile and deep analysis of the market, social culture, psychological features of the interest groups, their sympathies and repulsions. Despite the existing conflict, image is perceived as a fundamental attribute of an academic institution in creating favourable conditions for its performance and development. 
Prospects of the further research. The further research prospects include the scientific grounding of the model of formation of future teachers' readiness to creation of the higher education institution image in the master's preparation process.

\section{REFERENCES}

Baker, J. M. (2001). Marketing: critical perspectives on business and management, Vol. VI. London and New York: Routledge.

Balmer, J. M. T. (1999). Corporate Identity. The IEBM Encyclopedia of Marketing. London: International Business press.

Belanger, C. H., Bali, S., Longden B. (2014). How Canadian universities use social media to brand themselves. Tertiary Education and Management, 20, 14-29.

Bergami, M., Bagozzi R.P. (2000). Self-categorization, affective commitment and group selfesteem as distinct aspects of social identity in the organization. British Journal of Social Psychology, 39 (4), 555-577.

Boulding, K. (1956). The Image. University of M ichigan Press.

Browne, P. J., Golembiewski, R. T. (1974). The line-staff concept revisited: An empirical study of organizational images. Academy of M anagement Journal, 17, 407-417.

Csaszar, M., Wusching, T.A. (2015). Expanding geographical space on the global map of the university of Pecs's internationalization. Central European Higher Education Cooperation Conference Proceedings, July, (pp. 190-199).

Dowling, G.R. (1993). Developing your company image into a corporate asset. Long Range Planning, 26, 101-109.

Dutton, J. E., Dukerich, J. M. (1991). Keeping an eye on the mirror: image and identity in organizational adaptation. Academy of Management Journal, 34, 517-554.

Drūteikienè, G., Gudonienè, V., Marčinskas, A. (2007). Aukštojo mokslo instituciju ivaizdis: šališki veiksniai. Informacijos mokslai, T. 40, 25-38.

Drūteikienè, G. (2007). Organizacijos jvaizdžio valdymas. Vilnius: VU leidykla.

Drūteikienè, G., M arčinskas, A., M iškinis, A., Galinienè, B. (2009). The impact of study quality on the image of a higher education institution. Informacijos mokslai, T. 48, 68-81.

Helms, S. Key, C.H. (1994). Are students more than customers in the classroom? Quality Progress, 27 (9), 97-99.

Kotler, P., Fox, K. (1995). Strategic marketing for educational institutions. Upper Saddle River, NJ: Prentice-Hall.

Nagashima, A. A. (1977). Comparative 'made-in' product image survey among Japanese businessmen. Journal of M arketing, July, (pp. 95-100).

Nagashima, A. A. (1970). Comparison of Japanese and US attitudes toward foreign products. Journal of M arketing, January, (pp. 260-266).

Parameswaran, R. Glowacka, A. (1995). University image: An information processing perspective. Journal of M arketing for Higher Education, 6 (2), 41-56.

Бернейс, Э. (2013). Инженерия согласия. Полис. Политические исследования, 4, 122-131 (Bernays, E. (2013). Consent engineering. Polis. Political research, 4, 122-131).

\section{PEЗЮME}

Лохоня Николай. Теоретические основы формирования готовности будущих преподавателей к созданию имиджа учреждения высшего образования.

Образование является неотъемлемой частью жизни общества, от развития которой зависит интеллектуальный и духовный потенциал страны. $C$ проникновением в образовательную сферу рыночных отношений, глобализацией образовательных услуг, с одной стороны, и особенностями демографической 
ситуации в нашей стране, с другой, роль маркетинговых и PR-технологий в формировании имиджа высших учебных заведений сложно переоченить. Таким образом, теоретические основи формирования готовности будущих преподавателей к созданию имиджа учреждения высшего образования не только усиливает значимость отдельного университета, но и влияет на формирование имиджа образования в целом. Поэтому очень важно уделять формированию, поддержке и корректировке теоретических основ формирования готовности будущих преподавателей к созданию имиджа учреждения высшего образования.

Ключевые слова: теоретические основы, формирование, готовность будущих преподавателей, учреждение высшего образования, имидж.

\section{АНОТАЦІЯ}

Лохоня Микола. Теоретичні основи формування готовності майбутніх викладачів до створення іміджу закладу вищої освіти.

Освіта є невід'ємною частиною життя суспільства, від розвитку якої залежить інтелектуальний та духовний потенціал країни. Із проникненням в освітню сферу ринкових відносин, глобалізацією освітніх послуг, з одного боку, та особливостями демографічної ситуації в нашій країні, з іншого, роль готовності майбутніх викладачів до створення іміджу закладу вищої освіти складно переоцінити. Таким чином, теоретичні основи формування готовності майбутніх викладачів до створення іміджу закладу вищої освіти не тільки підсилює значимість окремого університету, а й впливає на формування іміджу освіти в иілому. Тому дуже важливо приділяти увагу формуванню, підтримці й коригуванню теоретичних основ формування готовності майбутніх викладачів до створення іміджу закладу вищої освіти. У статті розкрито сучасні теоретичні підходи до формування готовності майбутніх викладачів до створення іміджу закладу вищої освіти як елемента його конкурентоспроможності.

Конкуренція $\epsilon$ однією з найбільш важливих ознак ринкової економіки та розуміється як суперництво між суб'єктами ринку. Всі дії цих суб'єктів зі створення та збуту товарів і послуг, управління виробництвом, формування та реалізації стратегічних та тактичних завдань спрямовані на те, щоб визначити суперників, створити конкурентну перевагу. Конкуренція сприяє збагаченню пропозиції, ії пристосування до мінливих потреб населення, постійному виведенню на ринок нових, більш досконалих товарів і послуг.

Зміцнити власні позиції в конкурентному середовищі можна різними способами, у тому числі й за допомогою іміджу закладу вищої освіти. у статmі описані PR-технології, що застосовуються для формування готовності майбутніх викладачів до створення іміджу закладу вищої освіти: іміджу освітньої послуги, споживачів освітніх послуг, внутрішнього іміджу 3ВО, іміджу керівника, викладачів та студентів, візуального, соціального та бізнес-іміджу університету. Актуалізовані такі PR-технології, необхідні для побудови і реалізації імідж-системи в університеті, як media relations, event-marketing, спонсорство та благодійність, інвестор рілейшнз, технології тімбілдінга.

Ключові слова: теоретичні основи, формування, готовність майбутніх викладачів, заклад вищої освіти, імідж. 